\title{
PENGEMBANGAN BAHAN AJAR FISIKA KONTEKSTUAL BERBASIS INKUIRI TERBIMBING PADA MATERI ROTASI
}

\author{
Ahmad Zuhdi ${ }^{1}$ dan Ghery Priscilio ${ }^{2}$ \\ Pendidikan IPA, Sekolah Pascasarjana, Universitas Pendidikan Indonesia, Jl DR. Setiabudi No 229 \\ Isola Sukasari, Kota Bandung, 40154, Indonesia \\ E-mail: Ahmad.Zuhdi9@gmail.com
}

\begin{abstract}
ABSTRAK
Survey lapangan yang dilakukan di SMK di kota Malang menunjukkan adanya keterbatasan kualitas dan kuantitas bahan ajar yang digunakan dalama pembelajaran Fisika, padahal Fisika sangat penting sebagai dasar pembelajaran di SMK. Penelitian ini bertujuan untuk mengembangkan bahan ajar fisika yang kontekstual pada materi rotasi benda tegar untuk pembelajaran fisika di Sekolah Menengah Kejuruan (SMK). Bahan ajar ini berupa paket Buku Teks dan Animasi pembelajaran dengan pendekatan kontekstual yang menyajikan materi rotasi berdasarkan fenomena yang dekat dengan keseharian siswa. Metode penelitian yang digunakan adalah Research and Development (R\&D) dengan model pengembangan Borg dan Gall yang diawali dengan studi pendahuluan (studi kepustakaan dan kebutuhan lapangan) dilanjutkan dengan pengembangan produk dan validasi uji coba produk. Instrumen yang digunakan dalam penelitian ini berupa Lembar validasi ahli dan Kuesioner pada masing-masing Buku dan Animasi. Uji validitas dilakukan oleh 2 orang dosen jurusan Fisika, FMIPA Universitas Negeri Malang dengan memperhatikan aspek konten dan konstruk pada buku teks dan animasi dan uji keterbacaan bahan ajar diujikan kepada 40 orang siswa kelas X SMKN 6 Malang. Teknik analisis data digunakan pada penelitian ini adalah teknik persentase. Uji validasi konten dan konstruk bukudan animasi menunjukkan kategori valid dan bisa digunakan untuk membantu meningkatkan hasil pemahaman konsep.
\end{abstract}

Kata kunci: Bahan Ajar Fisika, Kontekstual, Rotasi, Research and Development (R\& D), Pendidikan Fisika

\begin{abstract}
Survey on Public Vacational High School in Malang city revealed that learning material of Physics need to be improved. This research aimed to develop the learning material of Physics using contextual approach particularly on Rotation in a package of text book and CD-Animation. This research used Research and Development (R\&D) based on Borg and Gall model which consist of three main stages, preliminary studies on literature review and necessity which are held by survey on Public Vacational High School in Malang City at 2013 then followed by designing and developing process and the last was validation by 2 expert of Learning material in Physics (2 Lecturer of Department of Physics Malang University) in both text book and CD-Animation by scrutinizing content and construct aspect. Validation also directed to 40 student of X grade in SMKN 6 Malang. Data was analyzed by percentage method. Validation showed that Learning material was valid.
\end{abstract}

Keywords: Physics Teaching material, Contextual, Rotation, Research and Development (R\&D), Physics Education

Received: 29 Januari 2019 ; Accepted: 1 Februari 2019 ; Published: 4 Februari 2019 


\section{PENDAHULUAN}

Pendidikan merupakan salah satu sa-rana untuk menciptakan sumber daya manusia yang berkualitas (Wirawan, Indrawati, \& Rahmanto, 2017). Pendidikan adalah salah satu faktor yang mempengaruhi perkembangan ilmu pengetahuan dan teknologi (Rahmawati, Hafnati Rahmatan, 2015). Salah satu masalah yang dihadapi dunia pendidikan adalah lemahnya proses pembelajaran (Benny Satria Wahyudi, Slamet Hariyadi, 2014). Belajar adalah serangkaian kegiatan fisik dan psikis seoseorang untuk memperoleh suatu perubahan tingkah laku sebagai hasil dari pengalaman individu dalam interaksi dengan lingkungannya yang menyangkut kognitif, afektif dan psikomotor (Junaedi, n.d.). Tujuan utama dari proses pembelajaran adalah bagaimana guru menyampaikan bahan ajar sehingga siswa mampu memahami nya atau siswa mampu belajar dari bahan ajar yang disampaikan guru (Anwar, 2017). Proses pembelajaran harus memberikan ruang lebih banyak kepada siswa untuk membangun pengetahuan baru berdasarkan pengetahuan yang telah diperoleh sebelumnya (Zaeni, Winaryati, \& Yuliyanto, 2018). Bahan Ajar merupakan segala bahan (baik informasi, alat, maupun teks) yang disusun secara sistemetis, yang menampilkan sosok utuh dari kompetensi yang akan dikuasai peserta didik (Prastowo, 2011). Bahan ajar yang baik tidak hanya memuat materi yang sesuai dengan kurikulum, tetapi harus ditulis dengan tingkat keterbacaan yang tinggi (Jatnika, 2014).

Permasalahan di sekolah saat ini bahan ajar yang tersedia masih kurang bervariatif (Priscylio, Rochintaniawati, \& Anwar, 2018). Bahan ajar yang tersedia kurang mampu meningkatkan proses berpikir dan keterampilan proses sains siswa (Ghery Priscylio, Mulyadi, 2018). Peran buku sangat besar karena buku dapat berperan sebagai sumber informasi, tetapi saat ini peserta didik juga memiliki kecenderungan kurangnya minat untuk membaca jika buku itu tebal dan kurang menarik (Asyhari \& Silvia, 2016). Untuk menunjang pembelajaran di kelas diperlukan sarana dan prasarana pendukung berupa alat bantu atau bahan ajar yang dapat meningkatkan motivasi belajar siswa, melatih nalar dan proses berpikir yaitu bahan ajar berbasis IPTEK (Muhammad Satriawan, 2016; Taufiq, Dewi, \& Widiyatmoko, 2014).

Fisika merupakan cabang Ilmu Pengetahuan Alam (IPA). Ilmu Fisika merupakan penunjang dalam berbagai kehidupan terutama dalam kemajuan teknologi, mulai dari teknologi yang sederhana maupun yang rumit (Nurhayati Ningsih, Prabowo, 2016). Pembelajaran IPA (Fisika) adalah pembelajaran yang tidak mengabaikan hakikat IPA (Fisika) sebagai sains. Hakikat sains yang dimaksud meliputi produk, proses, dan sikap ilmiah. Pembelajaran IPA (Fisika) seharusnya dapat memberikan pengalaman langsung pada siswa sehingga menambah kemampuan dalam mengkonstruksi, memahami, dan menerapkan konsep yang telah dipelajari (A. Doyan, M. Taufik, 2018). Agar peran siswa tidak hanya sebagai penerima melainkan juga secara aktif menggali dan membangun pengetahuan melalui pengalaman belajar yang bermakna (meaningfull learning) maka dibutuhkan suatu bahan ajar yang dapat meningkatkan motivasi dan minat siswa dalam belajar fisika, salah satunya yaitu dengan penggunaan bahan ajar berbasis komputer dan mengaitkan dengan fenomena - fenomena yang terjadi dalam kehidupan sehari - hari (A.A Gde Ekayana, Naswan Suharsono, 2013). Dengan adanya perkembangan dalam bidang ilmu pengetahuan dan teknologi diharapkan dapat dimanfaatkan untuk menunjang keefektifan kegiatan belajar mengajar (Setyawan, 2012). Penggunaan komputer sebagai media pembelajaran memungkinkan berlangsungnya proses pembelajaran sevara individual dengan menumbuhkan kemandirian dalam proses belajar sehingga siswa akan mengalami proses yang jauh lebih bermakna dibandingkan dengan pembelajaran secara konvensional (Kurnia Wening Sari, Sulistyo Saputro, 2014).

Bidang teknologi informasi yang semakin berkembang selaras dengan tuntutan zaman salah satunya adalah animasi. Penggunaan 
animasi sebagai media pembelajaran (computer based learning) memberikan keuntungan untuk meningkatkan pengetahuan dan ketrampilan siswa. Penggunaan animasi sebagai salah satu multimedia yang secara audio-visual mampu meningkatkan pemahaman siswa (RE, 2009). Macromedia flash sebagai salah satu program media pembelajaran disajikan dalam format tutorial yang sesuai digunakan untuk memahamkan materi-materi pelajaran pada siswa (Tri Yuwono, Mochamad Cholik, 2015). Maka pada penelitian ini kami telah mengembangkan bahan ajar fisika kontekstual berbasis inkuiri terbimbing pada materi rotasi untuk pembelajaran fisika di SMK. Bahan ajar yang dikembangkan terdiri dari buku cetak dan animasi. Penelitian ini mengadopsi tahapan inkuiri terbimbing. Desain inkuiri terbimbing oleh Hanson terdiri dari 5 tahapan yaitu Orientasi, Eksplorasi, Pembentukan Konsep, Aplikasi, dan Penutup (Ghery Priscylio, Andromeda, Mawardi, 2018). Instruksi yang berbasis Inkuiri memungkinkan siswa untuk terlibat dalam pembelajaran aktif seperti observasi, merumuskan pertanyaan, mengkaji literatur yang berhubungan, merencanakan investigasi, melakkukan percobaan dan mengambil data, menganalisis dan menginterpretasikan data, mengemukakan hasil (Arslan, 2014). Inkuiri juga memungkinkan siswa mempelajari bagaimana cara penemuan suatu konsep karena mereka terlibat langsung dalam menganalisis fenomena yang ada dalam merumuskan konsep (Wardani, Lindawati, \& Kusuma, 2017). Sekolah menengah kejuruan (SMK) merupakan jenjang pendidikan menengah yang mengutamakan pengembangan kemampuan peserta didik untuk dapat bekerja dalam bidang tertentu salah satunya yaitu pada bidang teknik otomotif (Iskandar, 2015).

\section{METODE PENELITIAN}

Metode yang digunakan dalam penelitian ini adalah Research and Development (R\&D) dengan menggunakan model pengembangan Borg dan Gall (Sugiyono, 2014; Sukmadinata, 2009).
Tujuan metode penelitian pengembangan untuk mengembangkan bahan ajar fisika kontekstual berbasis inkuiri terbimbing yang valid dan praktis untuk digunakan pada pembelajaran fisika di SMK. Model pengembangan dari Borg and Gall yang terdiri dari 10 langkah yaitu: (1) Research and information collecting (melakukan penelitian dan pengumpulan informasi), (2) Planning (melakukan perencanaan) (3) Develop preliminary from of product (mengembangkan bentuk produk awal), (4) Preliminary field testing (melakukan uji lapangan permulaan, (5) Main product revision (melakukan revisi terhadap produk utama, (6) Main field testing (melakukan uji lapangan utama), (7) Operational product revision (melakukan revisi produk), (8) Operational field testing (uji lapangan), (9) Final Product Revision (revisi produk akhir), (10) Dissemination and implementation (membuat laporan mengenai produk dan jurnal, bekerja dengan penerbit yang dapat melakukan distribusi secara komersial) (Sri Purnami, 2016). Sepuluh langkah itu diadaptasi menjadi 5 langkah yang kemudian dikelompokkan menjadi 3 langkah utama, yaitu (1) Studi Pendahuluan, (2) Pengembangan Produk, dan (3) Uji coba produk (Sukmadinata, 2009).

\section{Prosedur Penelitian}

Penelitian ini mengadaptasi tahap-tahap penelitian dan pengembangan Borg dan Gall yang diadaptasi sebagai berikut:

\section{Studi Pendahuluan}

\section{a. Studi Kepustakaan}

\section{1) Studi Kurikulum}

Studi kurikulum dilakukan dengan mengidentifikasi Standar Kompetensi dan Kompetensi Dasar mata pelajaran Fisika SMK pokok bahasan gerak rotasi.

\section{2) Analisis Sumber Belajar}

Analisis sumber belajar dilakukan dengan menganalisis buku-buku teks tentang gerak rotasi yang dapat dipertanggungjawabkan kebenarannya untuk melihat kesesuaian isi buku dengan 
Standar Kompetensi dan Kompetensi Dasar yang harus dicapai siswa, serta kemudahan dalam memanfaatkannya. Buku-buku yang telah sesuai akan digunakan sebagai acuan penyusunan konsep dan contoh soal serta latihan soal pada bahan ajar yang akan dikembangkan

b. Survei Lapangan

Survey lapangan dilakukan untuk mengetahui tingkat kebutuhan bahan ajar. Pengumpulan data dilakukan dengan wawancara kepada siswa kelas X semester II untuk mengetahui metode pembelajaran dan keadaan bahan ajar yang digunakan serta wawancara terhadap beberapa guru Fisika SMK.

\section{c. Pengembangan Draf Awal}

Berdasarkan hasil kajian pustaka dan survei lapangan terhadap kebutuhan bahan ajar, maka disusun draft sementara behan ajar yang akan dikembangkan. Draft ini berisi tentang cakupan materi yang akan dikembangkan serta tingkat keluasan dan kedalaman konsep materi yang diinginkan.

\section{Pengembangan Produk}

a. Anaisis SK dan KD serta Penyusunan Indikator Pencapaian Kompetensi

SK dan KD digunakan untuk menjabarkan cakupan materi yang akan dikembangkan serta tingkat kemampuan kognitif yang sesuai untuk SMK kelas X. Langkah selanjutnya adalah menjabarkan SK dan KD tersebut ke dalam indikator pencapaian kompetensi. Indikator pencapaian kompetensi dirumuskan dengan menggunakan kata kerja operasional yang dapat diamati, diukur, tidak bermakna ganda, yang mencangkup pengetahuan, sikap, dan keterampilan. Penyusunan indikator harus disesuaikan dengan Standar Kompetensi dan Kompetensi Dasar.

\section{b. Menyusun Lembar Kerja Siswa}

LKS dalam bahan ajar ini terdiri dari LKS praktikum dan LKS tentang pengamatan fenomena. LKS digunakan untuk mengarahkan siswa agar mempelajari konsep Fisika berdasarkan fenomena dan kegiatan yang akan diamati atau dilakkukan dalam kegiatan tersebut. LKS juga digunakan untuk mempermudah pemahaman siswa terhadap materi pelajaran.

c. Menyusun Bahan Ajar Cetak dan Animasi

Langkah ini dimulai dengan menyusun buku cetak dan selanjutnya mengembangkan animasi. Buku cetak disusun dengan memindahkan Kegiatan pembelajaran dan Lembar Kegiatan Siswa (LKS) yang telah dikembangkan tadi ke dalam format yang sistematis. Disamping mengembangkan buku cetak, dikembangkan juga animasi yang merupakan visualisasi dari konsep yang ada di dalam buku cetak. Animasi ini terdiri atas tampilan fenomena serta konsep teori yang mendukungnya sehingga di dalamnya terdapat video yang berisi fenomena dan alat-alat aplikasi konsep yang dipelajari. Kegiatan pertama yang dilakukan dalam pembuatan animasi adalah menyusun storyboard atau skenario tampilan animasi. Setelah itu, dilakukan pembuatan video fenomena dan kegiatan praktikum atau eksperimen yang dilakukan oleh penulis. Pembuatan video dilakukan dengan merekam fenomena dan percobaan secara langsung. Langkah selanjutnya adalah menggabungkan animasi dengan video fenomena dan praktikum.

\section{Uji Coba Produk}

\section{a. Desain Uji Coba Produk}

Uji coba produk dilakukan pada buku cetak dan animasi yang telah disusun kepada siswa. Setelah uji coba dilakukan, kekurangan-keurangan yang ada akan direvisi dan akan menjadi bahan ajar 
yang layak digunakan untuk pembelajaran.

b. Subjek Uji Coba

Tahap ini dilakukan dengan memberikan angket kepada ahli (dosen dan guru) fisika. Validasi dilakukan terhadap buku cetak dan animasi yang meliputi validasi kelayakan isi (konten) dan kelayakan penyajian isi dan bahasa (konstruk) oleh para ahli.

c. Instrumen Pengumpul Data

Instrumen yang digunakan dalam uji coba ini adalah kuosioner atau angket.

d. Teknik Analisis Data

Analisi data menggunakan teknik persentase dan mencocokan table kriteria. Rrumus pengolahan data kuantitatif dari angket validasi konten dan konstruk adalah sebagai berikut.

$$
P=\frac{\sum x}{\sum x_{i}} \times 100 \%
$$

\section{Keterangan :}

$P=$ Persentase

$\sum x=$ Jumlah skor jawaban tiap responden dari tiap item

$\sum x_{i}=$ jumlah total skor jawaban jika seluruh responde menjawab sama (Sugiyono, 2011).

Tabel 1. Kriteria Uji Coba Terbatas (Arikunto, 2008)

\begin{tabular}{cccc}
\hline No & Nilai & $\begin{array}{c}\text { Kriteria Valid } \\
\text { (untuk validator) }\end{array}$ & $\begin{array}{c}\text { Kriteria } \\
\text { (untuk subjek ujicoba) }\end{array}$ \\
\hline 1 & $80 \%-100 \%$ & Valid/layak & Baik \\
2 & $66 \%-79 \%$ & Cukup Valid/Cukup Layak & Cukup baik \\
3 & $56 \%-65 \%$ & Kurang Valid/Kurang Layak & Kurang baik \\
4 & $<56 \%$ & Tidak Valid/Tidak Layak & Tidak baik \\
\hline
\end{tabular}

\section{HASIL DAN PEMBAHASAN}

Produk hasil pengembangan penelitian ini berupa bahan ajar Fisika pada materi gerak rotasi. Bahan ajar ini berupa buku cetak dan CDAnimasi yang dapat digunakan oleh guru dalam pembelajaran di kelas dan sarana belajar mandiri bagi siswa. Buku dan animasi divalidasi oleh para ahli dari segi materi (konten) dan penyajian (konstruk). Para ahli ini terdiri dari dosen Fisika UM, guru Fisika SMKN 6 Malang, dan Mahasiswa Desain Komunikasi Visual. Selain validasi oleh para ahli, dilakukan juga uji coba terbatas pada pengguna. Pengguna merupakan siswa kelas X-TKR2 SMKN 6 Malang yang terdiri atas 30 siswa. Ketigapuluh siswa ini merupakan siswa program keahlian Teknik Kendaraan
Ringan (TKR). Hasil uji coba terbatas adalah sebagai berikut.

\section{Buku Teks}

Buku teks yang dikembangkan tampak sebagai berikut.
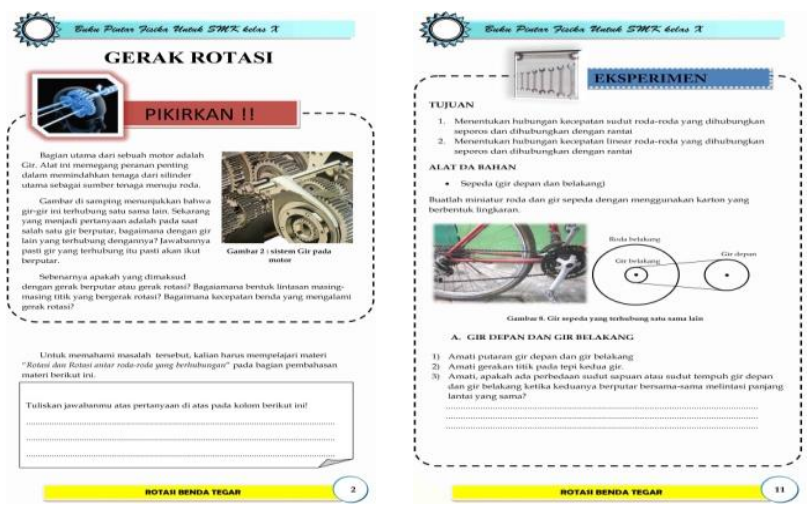

Gambar 1. Pengembangan Buku Teks Kontekstual dengan inkuiri terbimbing 
Validasi konten buku dilakukan oleh ahli yang terdiri atas dosen dan guru Fisika SMK. Hasil validasi konten buku dapat dilihat pada Tabel 2 dan Tabel 3.

Tabel 2. Data Kuantitatif Hasil Validitas Konten Buku Per Bagian Materi

\begin{tabular}{clcc}
\hline No & \multicolumn{1}{c}{ Bagian Materi } & Persentase (\%) & Keterangan \\
\hline 1 & Gerak Rotasi & 90,63 & Valid \\
2 & Rotasi roda-roda yang berhubungan & 90,28 & Valid \\
3 & Momen Inersia & 86,61 & Valid \\
4 & Momen Gaya & 94,1 & Valid \\
5 & Momen Gaya dan percepatan sudut & 90,63 & Valid \\
6 & Momentum Sudut & 92,36 & Valid \\
& Total & 90,8 & Valid \\
\hline
\end{tabular}

Tabel 3. Data Kuantitatif Hasil Validitas Konten Buku per Sub Aspek

\begin{tabular}{|c|c|c|c|c|}
\hline No & Aspek & Sub Aspek & $\begin{array}{c}\text { Persentase } \\
(\%)\end{array}$ & Keterangan \\
\hline \multirow[t]{11}{*}{1} & \multirow[t]{11}{*}{ Materi } & \multicolumn{3}{|l|}{ Kesesuaian materi dengan SK/KI dan KD } \\
\hline & & $\begin{array}{l}\text { a. Keluasan materi } \\
\text { (Sesuai dengan kegiatan yang akan dilakukan, } \\
\text { dijabarkan dari substansi minimal yang } \\
\text { terkandung dalam SK/KI dan KD) }\end{array}$ & 88,89 & Valid \\
\hline & & $\begin{array}{l}\text { b. Kedalaman materi } \\
\text { (penjabaran yang mendalam sesuai dengan SK } \\
\text { dan KD) }\end{array}$ & 84,72 & Valid \\
\hline & & Keakuratan materi & \multirow[t]{2}{*}{86,11} & \multirow[t]{2}{*}{ Valid } \\
\hline & & $\begin{array}{l}\text { c. Keakuratan konsep } \\
\text { (Penyajian konsep sesuai dengan kebenaran } \\
\text { teori IPA dan tidak menimbulkan banyak tafsir) }\end{array}$ & & \\
\hline & & $\begin{array}{l}\text { d. Kesesuaian notasi, simbol, dan satuan yang } \\
\text { terdapat dalam materi dengan acuan Sistem } \\
\text { Internasional (SI) }\end{array}$ & 95,83 & Valid \\
\hline & & $\begin{array}{l}\text { e. Keakuratan ilustrasi } \\
\text { (Pemberian ilustrasi sesuai dengan konsep IPA } \\
\text { yang dijelaskan dengan ukuran dan bentuk } \\
\text { yang proporsional serta dilengkapi dengan } \\
\text { keterangan yang tepat ) }\end{array}$ & 94,44 & Valid \\
\hline & & Materi Pendukung pembelajaran & \multirow[t]{2}{*}{86,11} & \multirow[t]{2}{*}{ Valid } \\
\hline & & $\begin{array}{l}\text { f. Kesesuaian dengan perkembangan ilmu dan } \\
\text { teknologi }\end{array}$ & & \\
\hline & & $\begin{array}{l}\text { g. Penggunaan contoh-contoh dan ilustrasi sesuai } \\
\text { dengan konsep yang benar }\end{array}$ & 98,61 & Valid \\
\hline & & $\begin{array}{l}\text { h. Kontekstual } \\
\text { (Penyajian materi, contoh, dan latihan berasal } \\
\text { dari lingkungan terdekat dan } \\
\text { akrab dengan kehidupan sehari-hari) }\end{array}$ & 98,61 & Valid \\
\hline \multirow[t]{3}{*}{2} & \multirow[t]{3}{*}{$\begin{array}{l}\text { Lembar } \\
\text { Kegiatan Siswa }\end{array}$} & $\begin{array}{l}\text { a. kejelasan Tujuan kegiatan siswa dan } \\
\text { kesesuaian dengan materi }\end{array}$ & 97,22 & Valid \\
\hline & & b. Kebenaran dan Keruntutan prosedur kegiatan & 94,44 & Valid \\
\hline & & c. Kesesuaaian prosedur pengamatan untuk & 94,44 & Valid \\
\hline
\end{tabular}




\begin{tabular}{|c|c|c|c|c|}
\hline No & Aspek & Sub Aspek & $\begin{array}{c}\text { Persentase } \\
(\%)\end{array}$ & Keterangan \\
\hline & & mencapai tujuan kegiatan siswa & & \\
\hline & & $\begin{array}{l}\text { d. Kesesuaian pertanyaan diskusi dan analisis soal } \\
\text { dengan konsep yang benar }\end{array}$ & 98,61 & Valid \\
\hline & & $\begin{array}{l}\text { e. Kesesuian prosedur, data dan pertanyaan } \\
\text { analisis untuk mencapai tujuan kegiatan siswa }\end{array}$ & 95,83 & Valid \\
\hline \multirow[t]{2}{*}{3} & Contoh Soal & a. Kebenaran Konsep contoh soal & 95,83 & Valid \\
\hline & & b. Kesesuaian contoh soal dengan materi & 87,5 & Valid \\
\hline \multirow[t]{2}{*}{4} & Latihan soal & a. Kesesuaian latihan soal dengan SK/KD & 90,28 & Valid \\
\hline & & b. Kesesuaian tingkat latihan soal dengan SK/KD & 84,72 & Valid \\
\hline \multirow[t]{3}{*}{5} & Info tambahan & a. Kebenaran Konsep dari Info tambahan & 81,94 & Valid \\
\hline & & b. Kesesuaian info dengan materi & 81,94 & Valid \\
\hline & & $\begin{array}{l}\text { c. Info-info yang disajikan dekat dengan } \\
\text { pengetahuan siswa }\end{array}$ & 95,83 & Valid \\
\hline \multirow[t]{3}{*}{6} & Latihan & a. Keseuaian soal evaluasi dengan SK/KD & 88,89 & Valid \\
\hline & Evaluasi Bab & & 20 & Wolid \\
\hline & & $\begin{array}{l}\text { b. Kebenaran soal evaluasi } \\
\text { c. Soal evaluasi logis dan kontekstual }\end{array}$ & $\begin{array}{l}90,28 \\
84,72\end{array}$ & $\begin{array}{l}\text { Valıd } \\
\text { Valid }\end{array}$ \\
\hline \multirow[t]{2}{*}{7} & Glosarium & $\begin{array}{l}\text { a. Kesesuaian pengertian pada masing-masing } \\
\text { item }\end{array}$ & 88,83 & Valid \\
\hline & & Total & 90,8 & Valid \\
\hline
\end{tabular}

Berdasarkan hasil validasi konten buku pada Tabel 2 dan Tabel 3 didapatkan persentase keseluruhan item sebesar 90,8\% dari nilai tertinggi $100 \%$ dan tergolong valid. Berdasarkan segi konten buku ini termasuk layak digunakan dengan revisi. Berdasarkan Tabel 2 ada beberapa butir angket yang mendapat nilai yang lebih rendah. Butir 1.b tentang kedalamanan materi (pendalaman materi sesuai dengan SKKD) mendapat nilai sebesar 84,72\%. Hal ini berarti perlu adanya revisi pada aspek penilaian ini. Butir 1f tentang kesesusian dengan perkembangan ilmu dan teknologi medapat poin $86,11 \%$ juga perlu dilakukan revisi pada bagian ini. Bagian lain yang perlu direvisi adalah butir $4 \mathrm{~b}$ tentang kesesuaian latihan soal dengan SK$\mathrm{KD}$, butir 5.a dan butir 5.b tentang info tambahan (kesesuaian dengan materi, dan kebenaran info tambahan), butir 6.c tentang latihan soal evaluasi (logis dan kontekstual). Analisis per bagian materi dari tiap butir angket mendapatkan nilai total sebesar 90,8\% yang masuk dalam kategori valid atau layak serta perlu adanya beberapa revisi. Bagian yang perlu mendapat revisi adalah materi momen inersia karenan mendapat nilai $86,61 \%$ yang lebih rendah dibanding materi lain.

\section{Data Validitas Kontruk Buku}

Validasi konstruk buku dilakukan oleh ahli yang terdiri atas dosen dan guru Fisika SMK. Hasil validasi konstruk buku dapat dilihat pada Tabel 4 dan Tabel 5.

Tabel 4. Data Kuantitatif Hasil Validitas Konstruk Buku per Bagian Materi

\begin{tabular}{clcc}
\hline No & Bagian Materi & $\begin{array}{c}\text { Persentase } \\
(\%)\end{array}$ & Keterangan \\
\hline 1 & Gerak Rotasi & 92,71 & Valid \\
2 & Rotasi roda- & 94,44 & Valid \\
& roda yang & & \\
& berhubungan & & \\
3 & Momen Inersia & 94,44 & Valid \\
4 & Momen Gaya & 93,98 & Valid \\
5 & Momen Gaya & 92,13 & Valid \\
& dan percepatan & & \\
& sudut & & \\
6 & Momentum & 94,44 & Valid \\
\hline
\end{tabular}




\section{Sudut}

93,60

Valid

Tabel 5. Data Kuantitatif Hasil Validitas Konstruk Buku per Sub Aspek

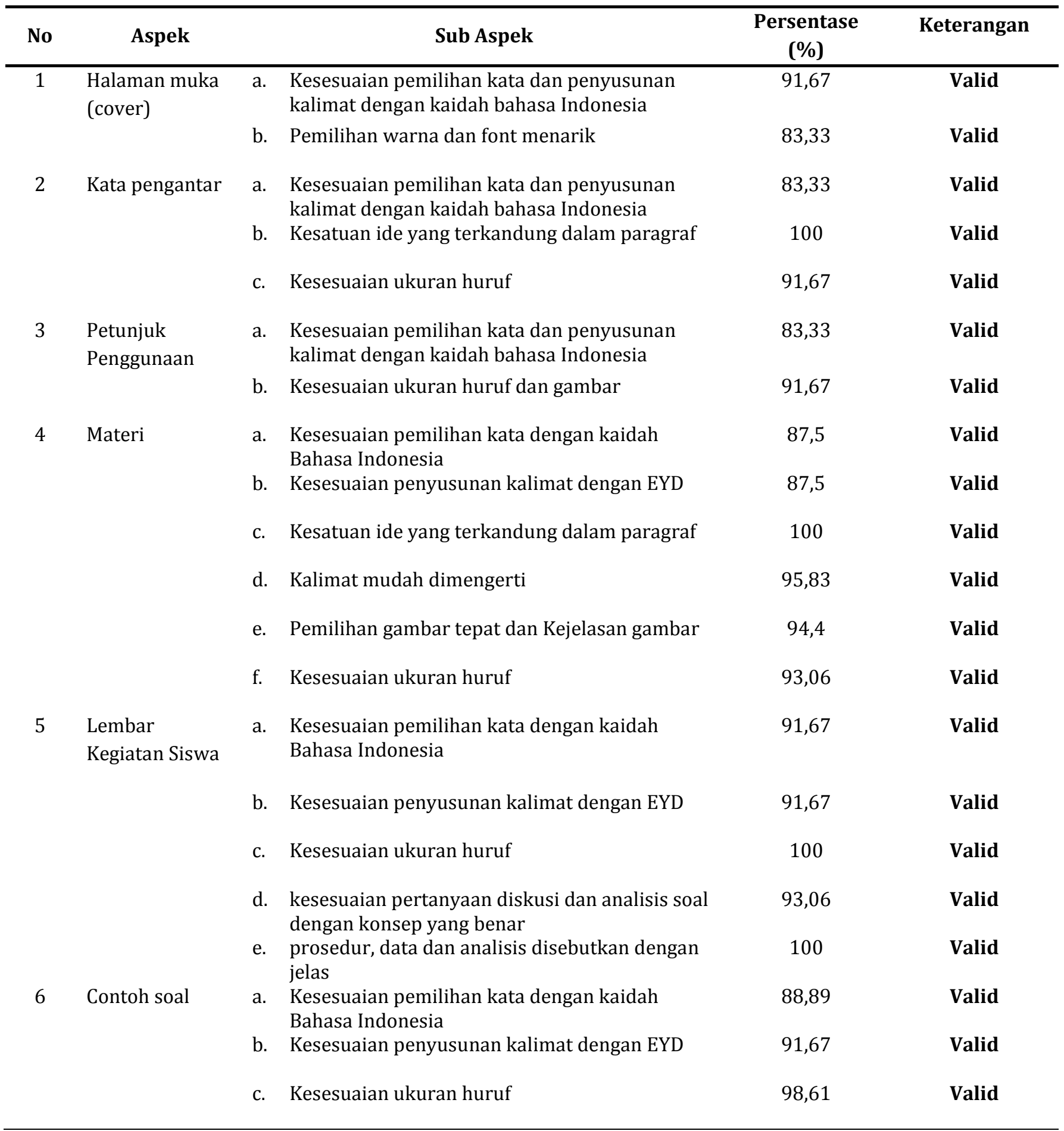




\begin{tabular}{|c|c|c|c|c|}
\hline No & Aspek & Sub Aspek & $\begin{array}{l}\text { Persentase } \\
\quad(\%)\end{array}$ & Keterangan \\
\hline \multirow[t]{2}{*}{7} & Latihan soal & $\begin{array}{l}\text { a. Kesesuaian pemilihan kata dan penyusunan } \\
\text { kalimat dengan kaidah Bahasa Indonesia }\end{array}$ & 91,67 & Valid \\
\hline & & b. Kesesuaian ukuran huruf & 100 & Valid \\
\hline \multirow[t]{2}{*}{8} & $\begin{array}{l}\text { Info-info } \\
\text { tambahan }\end{array}$ & $\begin{array}{l}\text { a. Kesesuaian pemilihan kata dan penyusunan } \\
\text { kalimat dengan kaidah Bahasa Indonesia }\end{array}$ & 87,5 & Valid \\
\hline & & b. Kesesuaian ukuran huruf & 95,83 & Valid \\
\hline \multirow[t]{2}{*}{9} & $\begin{array}{l}\text { Latihan evaluasi } \\
\text { bab }\end{array}$ & $\begin{array}{l}\text { a. Soal-soal disajikan dengan jelas dan mudah } \\
\text { dimengerti }\end{array}$ & 91,67 & Valid \\
\hline & & b. Kalimat sesuai dengan kaidah Bahasa Indonesia & 100 & Valid \\
\hline 10 & Glosarium & $\begin{array}{l}\text { a. Kalimat dan pemilihan kata sesuai dengan } \\
\text { kaidah bahasa Indonesia }\end{array}$ & 91,67 & Valid \\
\hline 11 & Daftar Pustaka & $\begin{array}{l}\text { a. Penullisan sudah sesuai dengan kaidah yang } \\
\text { benar }\end{array}$ & 91,67 & Valid \\
\hline \multirow[t]{3}{*}{12} & Keseluruhan & $\begin{array}{l}\text { a. Tata letak gambar dan huruf sudah sesuai dan } \\
\text { mudah dilihat }\end{array}$ & 83,33 & Valid \\
\hline & & b. Pemilihan warna sudah sesuai & 83,33 & Valid \\
\hline & & Total & 92,1 & Valid \\
\hline
\end{tabular}

Berdasarkan data validasi konstruk buku pada angket penilaian umum yang tercantum pada Tabel 4 didapatkan persentase keseluruhan item sebesar $92,1 \%$ dari nilai tertinggi $100 \%$ dan tergolong valid. Berdasarkan segi konstruk, keseluruhan buku ini termasuk layak digunakan dengan revisi. Angket penilaian khusus yang tercantum pada Tabel 5 menyatakan bahwa nilai total untuk semua butir sebesar 93,89\% dari nilai maksimal sebesar $100 \%$.

\section{Uji Coba Terbatas Buku}

Berdasarkan hasil uji coba terhadap 30 siswa yang terlihat pada Tabel 6 didapatkan hasil 85\%

Tabel 6. Data Kuantitatif Hasil Uji Coba Terbatas Buku menjawab ya dan $8 \%$ menjawab ragu-ragu dan $5 \%$ menjawab tidak. Hal ini berarti secara keseluruhan buku ini termasuk valid/baik. Butir 5 tentang tulisan dan gambar pada bagian "pikirkan" mendapat nilai 73\% siswa mejawab ya dan $23 \%$ menjawab ragu-ragu dan 3\% menjawab tidak. Hal ini berarti bagian ini masuk dalam kategori cukup baik dan perlu direvisi. Butir 7 tentang tulisan dan gambar pada bagian "pembahasan materi" mendapat nilai $77 \%$ menjawab ya, $17 \%$ menjawab ragu-ragu dan $7 \%$ menjawab tidak.

\begin{tabular}{|c|c|c|c|c|}
\hline No & Kriteria & $\begin{array}{c}\text { Ya } \\
(\%)\end{array}$ & $\begin{array}{l}\text { Ragu-Ragu } \\
(\%)\end{array}$ & $\begin{array}{c}\text { Tidak } \\
(\%)\end{array}$ \\
\hline 1 & Apakah tulisan pada cover dapat dibaca dengan jelas? & 90 & 7 & 3 \\
\hline 2 & Apakah petunjuk penggunaan buku jelas? & 97 & 3 & 0 \\
\hline 3 & $\begin{array}{l}\text { Apakah dengan adanya daftar isi mempermudah pencarian halaman yang } \\
\text { dimaksud? }\end{array}$ & 87 & 7 & 3 \\
\hline
\end{tabular}


JoTaLP: Journal of Teaching and Learning Physics 4, 1 (2019): 50-64

Website: http://journal.uinsgd.ac.id/index.php/jtlp/index ISSN 2580-3107 (online) ISSN 2528-5505 (print)

\begin{tabular}{|c|c|c|c|c|}
\hline No & Kriteria & $\begin{array}{l}\text { Ya } \\
(\%)\end{array}$ & $\begin{array}{l}\text { Ragu-Ragu } \\
(\%)\end{array}$ & $\begin{array}{l}\text { Tidak } \\
(\%)\end{array}$ \\
\hline 4 & Apakah tulisan subjudul dapat terbaca dengan jelas? & 80 & 3 & 3 \\
\hline 5 & $\begin{array}{l}\text { Apakah tulisan dan gambar pada bagian "pikirkan" dapat terbaca dengan } \\
\text { jelas? }\end{array}$ & 73 & 23 & 3 \\
\hline 6 & $\begin{array}{l}\text { Apakah tulisan dan gambar pada bagian "eksperimen" dapat terbaca } \\
\text { dengan jelas? }\end{array}$ & 90 & 3 & 7 \\
\hline 7 & $\begin{array}{l}\text { Apakah tulisan dan gambar pada bagian "pembahasan materi" dapat } \\
\text { terbaca dengan jelas? }\end{array}$ & 77 & 17 & 7 \\
\hline 8 & $\begin{array}{l}\text { Apakah tulisan dan gambar pada bagian "contoh soal dan latihan soal" } \\
\text { dapat terbaca dengan jelas? }\end{array}$ & 83 & 10 & 7 \\
\hline 9 & $\begin{array}{l}\text { Apakah tulisan dan gambar pada bagian "evaluasi" dapat terbaca dengan } \\
\text { jelas? }\end{array}$ & 87 & 10 & 3 \\
\hline \multirow[t]{2}{*}{10} & Apakah Glosarium, indeks, dan daftar pustaka dapat terlihat dengan jelas? & 90 & 0 & 10 \\
\hline & Total & 85 & 8 & 5 \\
\hline
\end{tabular}

\section{CD Animasi}

CD Animasi yang dikembangkan tampak seperti gambar 2 berikut ini.
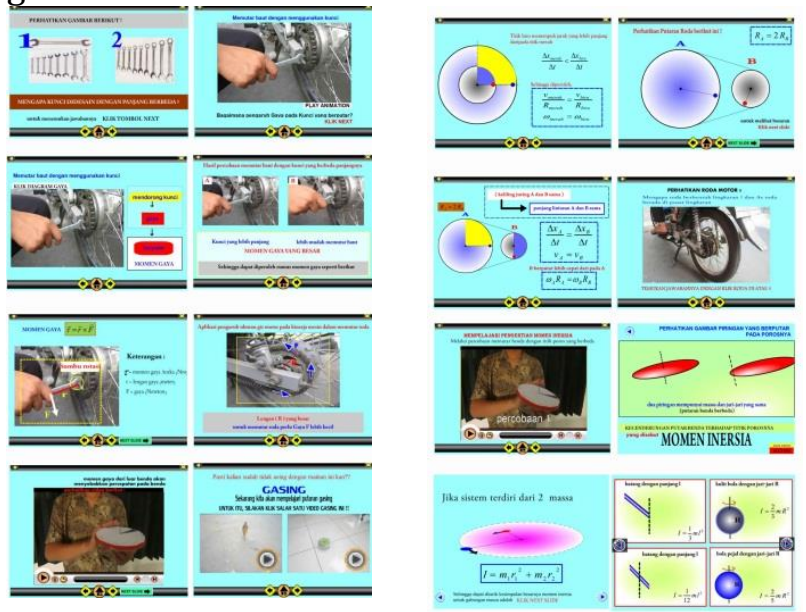

Gambar 2. Tampilan CD-Animasi

\section{Data Validitas Konten CD Animasi}

Berdasarkan hasil validasi konten animasi seperti yang terlihat pada Tabel 7 dan Tabel 8 didapatkan persentase keseluruhan item sebesar $90,06 \%$ dari nilai tertinggi $100 \%$ dan tergolong valid. Berdasarkan Tabel 7, ada beberapa butir angket yang mendapat nilai yang lebih rendah dibanding dengan butir lainya. Butir 5 tentang kemudahan penjelasan materi mendapat nilai $87,5 \%$ yang lebih rendah dibanding dengan butir yang lainnya. Analisis data validasi konten per bagian materi juga mendapatkan hasil bahwa ada materi yang mendapat nilai lebih rendah dibanding dengan materi lain.

Tabel 7. Data Kuantitatif Hasil Validitas Konten CD Animasi

\begin{tabular}{clcc}
\hline No & \multicolumn{1}{c}{ Aspek } & Persentase (\%) & Keterangan \\
\hline $\mathbf{1}$ & Materi telah sesuai dengan SK dan KD & 93,06 & Valid \\
$\mathbf{2}$ & Materi telah sesuai dengan konsep Fisika & 91,67 & Valid \\
$\mathbf{3}$ & Materi disajikan secara runtut & 100 & Valid \\
$\mathbf{4}$ & Penyajian materi telah jelas & 90,28 & Valid \\
$\mathbf{5}$ & Pembahasan materi mudah dimengerti & 87,5 & Valid \\
$\mathbf{6}$ & Gambar dan animasi telah sesuai dengan materi & 90,28 & Valid \\
$\mathbf{7}$ & Narasi telah sesuai dengan materi & 91,67 & Valid \\
\hline
\end{tabular}


JoTaLP: Journal of Teaching and Learning Physics 4, 1 (2019): 50-64

Website: http://journal.uinsgd.ac.id/index.php/jtlp/index ISSN 2580-3107 (online) ISSN 2528-5505 (print)

Total

92,06

Valid

Tabel 8. Data Kuantitatif Hasil Validasi Konten Animasi per Bagian Materi

\begin{tabular}{|c|c|c|c|}
\hline No & Bagian Materi & Persentase (\%) & Keterangan \\
\hline 1 & Gerak Rotasi & 94,05 & Valid \\
\hline 2 & Rotasi roda-roda yang berhubungan & 94,05 & Valid \\
\hline 3 & Momen Inersia & 89,29 & Valid \\
\hline 4 & Momen Gaya & 91,67 & Valid \\
\hline 5 & Momen Gaya dan percepatan sudut & 91,67 & Valid \\
\hline 6 & Momentum Sudut & 91,67 & Valid \\
\hline & Total & 92,06 & Valid \\
\hline
\end{tabular}

\section{Data Validitas Kontruk Animasi}

Berdasarkan Tabel 9 tentang penilaian animasi secara keseluruhan (umum), ada beberapa butir angket yang mendapat nilai yang lebih rendah dibanding dengan butir lainya. Butir 1 mendapat nilai $75 \%$ yang berarti tampilan home menu perlu direvisi. Bagain lain yang mendapat nilai lebih rendah adalah bagian butir 5 tentang tingkat kemudahan pengoperasian animasi. Butir ini mendapat nilai $75 \%$. Kedua butir tersebut mendapat poin $75 \%$ yang berarti bagian ini termasuk dalam kriteria cukup valid.
Berdasarkan Tabel 10 tentang penilaian animasi secara khusus per aspek/kategori, didapatkan beberapa butir yang mendapat nilai labih rendah. Butir 4 tetang kesesuaian pemilihan warna dan butir 6 tentang kesesuaian penempatan gambar dan animasi mendapat poin yang sama sebesar 77,78\%. Berdasarkan Tabel 11 tentang penilaian animasi secara khusus per materi, didapatkan beberapa butir yang mendapat nilai labih rendah. Materi rotasi rodaroda berhubungan, momen inersia serta momen gaya dan percepatan sudut mendapat skor $79,76 \%$.

Tabel 9. Data Kuantitatif Hasil Validitas Konstruk Animasi (Penilaian Umum)

\begin{tabular}{clcc}
\hline No & \multicolumn{1}{c}{ Aspek } & $\begin{array}{c}\text { Persentase } \\
\text { (\%) }\end{array}$ & Keterangan \\
\hline 1 & Tampilan halaman home menu menarik & 75 & Cukup valid \\
2 & $\begin{array}{l}\text { Penggunaan tombol telah sesuai dengan kegunaannya, (Misal: } \\
\text { tombol help menuju ke halaman help) }\end{array}$ & 92 & Valid \\
3 & $\begin{array}{l}\text { Tampilan halaman materi telah sesuai untuk digunakan dalam } \\
\text { media pembelajaran ini. }\end{array}$ & 83 & Valid \\
$4 \quad \begin{array}{l}\text { Pemilihan bentuk tombol telah sesuai untuk digunakan dalam } \\
\text { media pembelajaran ini. }\end{array}$ & 92 & Valid \\
& $\begin{array}{l}\text { Media pembelajaran yang dikembangkan ini mudah dalam } \\
\text { menjalankannya (user friendly) }\end{array}$ & 75 & Cukup valid \\
& Total & $\mathbf{8 3}$ & Valid \\
\hline
\end{tabular}

Tabel 10. Data Kuantitatif Hasil Validitas Konstruk Animasi (Penilaian Khusus)

\begin{tabular}{cccc}
\hline No & Aspek & $\begin{array}{c}\text { Persentase } \\
(\%)\end{array}$ & Keterangan \\
\hline 1 & Peilihan jenis huruf telah sesuai & 80,56 & Valid
\end{tabular}




\begin{tabular}{|c|c|c|c|}
\hline No & Aspek & $\begin{array}{c}\text { Persentase } \\
(\%)\end{array}$ & Keterangan \\
\hline 2 & Pemilihan warna teks telah sesuai & 83,33 & Valid \\
\hline 3 & $\begin{array}{l}\text { Pemilihan warna background telah sesuai dengan media } \\
\text { pempelajaran ini }\end{array}$ & 83,33 & Valid \\
\hline 4 & Komposisi pemilihan warna telah sesuai & 77,78 & Cukup Valid \\
\hline 5 & Gambar dan animasi menarik & 79,17 & Cukup Valid \\
\hline 6 & Penempatan gambar dan animasi telah sesuai & 77,78 & Cukup Valid \\
\hline \multirow[t]{2}{*}{7} & Animasi telah jelas dan mudah dipahami & 81,94 & Valid \\
\hline & Total & 80,56 & Valid \\
\hline
\end{tabular}

Tabel 11. Data Kuantitatif Hasil Validitas Konstruk Animasi Per Bagian Materi

\begin{tabular}{clcc}
\hline No & \multicolumn{1}{c}{ Bagian Materi } & Persentase (\%) & Keterangan \\
\hline 1 & Gerak Rotasi & 82,14 & Valid \\
2 & Rotasi roda-roda yang berhubungan & 79,76 & Cukup Valid \\
3 & Momen Inersia & 79,76 & Cukup Valid \\
4 & Momen Gaya & 80,95 & Valid \\
5 & Momen Gaya dan percepatan sudut & 79,76 & Cukup Valid \\
6 & Momentum Sudut & 80,95 & Valid
\end{tabular}

\section{Data Hasil Uji Coba Terbatas Animasi}

Berdasarkan hasil uji coba terhadap 30 siswa yang terlihat pada Tabel 12 didapatkan hasil 86 $\%$ menjawab ya, 10\% menjawab ragu-ragu dan $3 \%$ menjawab tidak. Butir 2 tentang tombol navigasi mendapat nilai $87 \%$ siswa menjawab ya, $10 \%$ siswa menjawab ragu-ragu dan 1\% menjawab tidak. Hal ini menunjukkan bahwa sistem navigasi pada animasi tergolong kategori baik dan perlu direvisi. Butir 3 tentang tombol Exit dan Back to main menu mendapat nilai $82 \%$ menjawab ya, $12 \%$ menjawab ragu-ragu dan $5 \%$ menjawab tidak. Aspek tombol Exit dan Back to main menu masuk kategori baik. Berdasarkan analisis data kuantitatif hasil uji coba terbatas animasi per bagian materi seperti yang terlihat pada Tabel 13, didapatkan nilai total $86 \%$ menjawab ya, $10 \%$ menjawab ragu-ragu dan $3 \%$ menjawab tidak. Hal ini berarti bahwa animasi ini masuk dalam kategori baik dan perlu revisi. Bagian materi yang perlu direvisi adalah gerak rotasi, rotasi roda-roda berhubungan serta momen gaya dan percepatan sudut.

Tabel 12. Data Kuantitatif Hasil Uji Coba Terbatas Animasi per Aspek

\begin{tabular}{clccc}
\hline No & \multicolumn{1}{c}{ Kriteria } & Ya (\%) & Ragu-Ragu (\%) & $\begin{array}{c}\text { Tidak } \\
\text { (\%) }\end{array}$ \\
\hline 1 & Apakah huruf dan gambar dapat terlihat dengan jelas ? & 90 & 8 & 2 \\
2 & $\begin{array}{l}\text { Apakah tombol navigasi halaman mudah dioperasikan dan } \\
\text { mudah ditemukan? }\end{array}$ & 87 & 10 & 1 \\
3 & $\begin{array}{l}\text { Apakah tombol navigasi exit dan back to main menu mudah } \\
\text { ditemukan? }\end{array}$ & 82 & 12 & 5 \\
& Total & $\mathbf{8 6}$ & $\mathbf{1 0}$ & $\mathbf{3}$ \\
\hline
\end{tabular}


Tabel 13. Data Kuantitatif Hasil Uji Coba Terbatas Animasi per Bagian Materi

\begin{tabular}{|c|c|c|c|c|}
\hline No & Bagian Materi & $\begin{array}{l}\text { Ya } \\
(\%)\end{array}$ & $\begin{array}{c}\text { Ragu- } \\
\text { ragu } \\
(\%) \\
\end{array}$ & $\begin{array}{c}\text { Tidak } \\
\text { (\%) }\end{array}$ \\
\hline 1 & Home menu & 84 & 12 & 3 \\
\hline 2 & Gerak rotasi & 74 & 19 & 6 \\
\hline 3 & Momen Inersia & 89 & 8 & 3 \\
\hline 4 & Momen Gaya & 89 & 8 & 1 \\
\hline 5 & $\begin{array}{l}\text { Momen Gaya dan } \\
\text { percepatan sudut }\end{array}$ & 87 & 9 & 2 \\
\hline 6 & Momentum Sudut & 88 & 9 & 3 \\
\hline \multirow[t]{2}{*}{7} & Help dan Profil & 93 & 6 & 1 \\
\hline & Total & 86 & 10 & 3 \\
\hline
\end{tabular}

\section{KESIMPULAN}

Validasi menghasilkan data validasi konten buku yaitu 90,8\% tergolong valid/layak . Hasil validasi konstruk buku yaitu 92,1\% tergolong pada valid/layak sedangkan hasil dari subjek uji coba terhadap 30 siswa didapatkan hasil $85 \%$ menjawab ya, $8 \%$ menjawab ragu-ragu dan 5\% menjawab tidak. Hasil validasi konten animasi secara keseluruhan mendapatkan nilai sebesar 92, 06\% sehingga tergolong valid/layak. Hasil validasi konstruk animasi mendapatkan nilai sebesar $80,56 \%$ sehingga tergolong valid/layak. Uji coba terhadap 30 siswa didapatkan hasil 86\% menjawab ya, $10 \%$ menjawab ragu-ragu dan 3\% menjawab tidak. Hasil keseluruhan ini menunjukkan bahwa bahan ajar yang terdiri atas buku dan CD-Animasi ini valid/layak dengan revisi. Setelah dilakukan revisi maka buku dan CD-Animasi ini dapat digunakan sebagai bahan ajar dalam pembelajaran Fisika pada materi gerak rotasi untuk SMK.

Pemanfaatan bahan ajar ini sebaiknya disertai dengan media berupa alat nyata (autentik). Peneliti lain yang akan mengembangkan bahan ajar Fisika untuk SMK agar menemukan dan menyajikan contoh-contoh fenomena dan aplikasi sederhana lainnya yang ada di lingkungan siswa SMK. CD-Animasi yang digunakan sebagai media pembelajaran sebaiknnya ditambahkan bagian evaluasi yang bisa berupa pertanyaan-pertanyaan atau soalsoal tentang fenomena atau aplikasi sehingga evaluasi akan terasa menarik bagi siswa.

Pengembangan animasi menggunakan Swishmax perlu mempertimbangkan timing yang tepat, khususnya dalam memberikan narasi suara pada sprite dan animasi. Pengembang sebaiknya menghindari file suara pada sprite dan scene atau antar sprite yang berada di frame yang berdekatan dalam satu scene akan saling bertumpukan jika di play bersama. Kehalusan gerakan benda dapat juga dialakukan dengan memodifikasi efek move dengan teknik easing yang tepat.

\section{DAFTAR PUSTAKA}

A. Doyan, M. Taufik, R. A. (2018). Pengaruh Pendekatan Multi Representasi Terhadap Hasil Belajar Fisika Ditinjau Dari Motivasi Belajar Peserta Didik. Jurnal Penelitian Pendidikan IPA, 4(1), 35-45.

A.A Gde Ekayana, Naswan Suharsono, I. M. T. (2013). Pengembangan Perangkat Pembelajaran Mikrokontroler Berbasis Advance Virtual Risc (AVR) Dalam Mata Pelajaran Teknik Mikrokontroler. E-Journal Program Pascasarjana Universitas Pendidikan Ganesha, 3.

Anwar, S. (2017). Pengolahan Bahan Ajar. Bandung: Universitas Pendidikan Indonesia.

Arikunto, S. (2008). Dasar-Dasar Evaluasi Pendidikan. Jakarta: Bumi Aksara.

Arslan, A. (2014). Transition between Open and Guided Inquiry Instruction. Procedia - Social and Behavioral Sciences, 141, 407-412. https://doi.org/10.1016/j.sbspro.2014.05.0 71

Asyhari, A., \& Silvia, H. (2016). Pengembangan Media Pembelajaran Berupa Buletin dalam Bentuk Buku Saku untuk Pembelajran IPA Terpadu. Jurnal Ilmiah Pendidikan Fisika AlBiruni, 5(1), 1-13. 
https://doi.org/10.24042/jpifalbiruni.v5i1. 100

Benny Satria Wahyudi, Slamet Hariyadi, S. A. H. (2014). Pengembangan Bahan Ajar Model Problem Based Learning Pada Pokok Bahasan Pencemaran Lingkungan Untuk Meningkatkan Hasil Belajar Siswa Kelas X SMA Negeri Grujungan Bondowoso. Pancaran, 3(3), 83-92.

Ghery Priscylio, Andromeda, Mawardi, D. R. (2018). Development of Guided Inquiry Experiment Student Worksheet on the Topic of Acid and Base Grade XI to Find the Concepts of Chemistry. In Matematics, Science and Computer Science Education Seminar (MSCEIS).

Ghery Priscylio, Mulyadi, D. R. (2018). Needs of integrated science experiment student worksheet in junior high school to improve students science process skills. In International Conference on Mathematics and Science Education (ICMScE).

Iskandar, S. (2015). The Development of Problem Based Learning Model in Troubleshooting to Enhance Students Critical Thinking Skills at Automotive Program of Senior Vocational School. Edutech, 1(2).

Jatnika, A. W. (2014). Tingkat Keterbacaan Wacana Sains Dengan Teknik Klos. Jurnal Sosioteknologi, 6(10), 196-200. Retrieved from

http://journals.itb.ac.id/index.php/sostek/ article/view/972

Junaedi, D. (n.d.). Desain Pembelajaran Model ADDIE, 1-14. Retrieved from https://www.padamu.net/desainpembelajaran-model-addie

Kurnia Wening Sari, Sulistyo Saputro, B. H. (2014). Pengembangan Game Edukasi Kimia Berbasis Role Playing Game ( RPG ) Pada Materi Struktur Atom Sebagai Media Pembelajaran Mandiri Untuk Siswa Kelas X SMA di Kabupaten Purworejo, 3(2), 96-104. Muhammad Satriawan, R. (2016). Pengembangan Bahan Ajar Fisika Berbasis Kontekstual Dengan Mengintegrasikan Kearifan Lokal Untuk Meningkatkan
Pemahaman Konsep Siswa Pada Mahasiswa. Pendidikan Sains Pascasarjana Universitas Negeri Surabaya, 6(1), 1-7.

Nurhayati Ningsih, Prabowo, W. W. (2016). Pengembangan Media Pembelajaran Berbasis Role Playing Game (RPG) Maker XP Pada Materi Kesetimbangan Benda Tegar Untuk Melatihkan Keterampilan Berpikir Kritis Siswa. Pendidikan Sains Pascasarjana Universitas Negeri Surabaya, 6(1), 1107-1112.

Prastowo, A. (2011). Panduan Kreatif Membuat Bahan Ajar Inovatif. Yogyakarta: Diva Press.

Priscylio, G., Rochintaniawati, D., \& Anwar, S. (2018). Needs of integrated science textbook for junior high school based on learning style ( descriptive research ). In International Conference on Mathematics and Science Education (ICMSCE). Bandung: Universitas Pendidikan Indonesia.

Rahmawati, Hafnati Rahmatan, H. (2015). Penerapan Bahan Ajar Media Komik Pada Konsep Fotosintesis Untuk Meningkatkan Hasil Belajar Peserta Didik di SMP Islam Darul Ulum Banda Aceh. Jurnal EduBio Tropika, 3(1), 33-36.

RE, M. (2009). Multimedia learning (2nd ed.). New York: Cambridge UniversityPress.

Setyawan, A. (2012). Pengembangan Media Pembelajaran Berbasis Adobe Flash Professional Cs6 Pada Mata Kuliah Hidrolika Di Jurusan Teknik Sipil dan Perencanaan Universitas Negeri Yogyakarta. Ekonomi \& Pendidikan, 8(20), 58.

Sri Purnami, I. N. S. (2016). Pengembangan Pembelajaran Senam Lantai Menggunakan Media E- Learning Untuk Siswa SMP Negeri Se Kecamatan Pagak Kabupaten Malang. Motion, VII(2), 183-190.

Sugiyono. (2011). Metode peneitian kombinasi (Mixed Methods). Bandung: Alfa Beta.

Sugiyono. (2014). Metode Penelitian Pendidikan. Bandung: Alfa Beta.

Sukmadinata, N. S. (2009). Metode Penelitian Pendidikan. Bandung: PT. Remaja Rosdakarya. 
Taufiq, M., Dewi, N. R., \& Widiyatmoko, A. (2014). Pengembangan Media Pembelajaran IPA Terpadu Berkarakter Peduli Lingkungan Tema “ Konsevasi” Berpendekatan Science Edutainment. Jurnal Pendidikan IPA Indonesia, 3(2), 140-145.

Tri Yuwono, Mochamad Cholik, M. (2015). Pengembangan Perangkat Pembelajaran Berbasis Macromedia Flash Pada Kompetensi Mengoperasikan Mesin Frais Melalui Pembelajaran Langsung Untuk Siswa Kelas XI SMK Program Studi Teknik Mesin. Jurnal Pendidikan Vokasi : Teori Dan Praktek, 3(1), 21-30.

Wardani, S., Lindawati, L., \& Kusuma, S. B. W. (2017). The development of inquiry by using android-system-based chemistry board game to improve learning outcome and critical thinking ability. Jurnal Pendidikan IPA Indonesia, 6(2), 196-205. https://doi.org/10.15294/jpii.v6i2.8360

Wirawan, A. W., Indrawati, C. D. S., \& Rahmanto, A. N. R. (2017). Pengembangan media pembelajaran kearsipan digital untuk meningkatkan hasil belajar siswa SMK Negeri 3 Surakarta. Jurnal Pendidikan Vokasi, $\quad 7(1), \quad 78$. https://doi.org/10.21831/jpv.v7i1.12879

Zaeni, J. A., Winaryati, E., \& Yuliyanto, E. (2018). Development of " Pop -Up Book for Kids " as a Learning Media Science theme " Perubahan Cuaca " for Student of Class 3 Elementary School. In International Seminar on Education and Development of Asia 1st INseIDEA Saturday, July 14th, 2018 Development (pp. 1-9). 